\title{
MORPHOLOGY AND ANATOMY OF A LEAF MINE IN Vismia guianensis (AUBL.) CHOISY (CLUSIACEAE) IN A FRAGMENT OF BRAZILIAN ATLANTIC FOREST
}

\author{
ALMEIDA-CORTEZ, J. S. ${ }^{1}$ and MELO-DE-PINNA, G. F. A. ${ }^{2}$ \\ ${ }^{1}$ Departamento de Botânica, Universidade Federal de Pernambuco, \\ Rua Prof. Nelson Chaves, s/n, CEP 50372-970, Recife, PE, Brazil \\ ${ }^{2}$ Departamento de Botânica, Instituto de Biociências, Universidade de São Paulo, \\ Rua do Matão, C. P. 11461, Cidade Universitária, CEP 05422-970, São Paulo, SP, Brazil \\ Correspondence to: Jarcilene Almeida-Cortez, Departamento de Botânica, Universidade Federal de Pernambuco, \\ Rua Prof. Nelson Chaves, s/n, CEP 50372-970, Recife, PE, Brazil, e-mail: jacortez@ufpe.br \\ Received December 17, 2004 - Accepted March 1, 2005 - Distributed May 31, 2006 \\ (With 2 figures)
}

\begin{abstract}
Mines or hyponomes are channels caused by larva miners consuming internal plant tissues. These miners live on the leaf and feed from these tissues. Leaf mines are usually visible on the exterior of the leaf as serpentine paths, blotches, or other characteristic shapes of discolored tissues. Morphological and structural modifications undergone by mined leaves of Vismia guianensis (Aubl.) Choisy are presented here with the purpose of elucidating their structure and to contribute to studies about insect-plant interactions. Healthy and mined leaves were harvested from thirty plants and taken to the laboratory. For each branch, the total number of young and mature leaves, the number of leaves with mines and the number of mine per leaf were counted. Transverse sections of healthy and mined leaves were obtained to observe the morpho-anatomic aspects. From the 1,438 mature leaves and 379 young leaves analyzed, $214(14.9 \%)$ and $70(18.5 \%)$ were mined, where most of the leaves $(67 \%)$ presented one mine per leaf. Transverse sections of the mine revealed that the larva consumed only mesophyll parenchyma tissue and the epidermis remains intact. There is not a pattern of leaf mining, but the larvae did not consume the druses observed on mesophyll and the vascular tissues of the mid-vein and lateral vein.
\end{abstract}

Keywords: plant anatomy, hyponomes, leaf mine, plant-herbivores interactions, Clusiaceae.

\section{RESUMO}

\section{Morfologia e anatomia da mina foliar de Vismia guianensis (Aubl.) Choisy (Clusiaceae) ocorrente em um fragmento de floresta Atlântica brasileira}

Minas ou hiponomas são canais causados pelo consumo de tecidos internos da planta por larvas minadoras que habitam na folha e se alimentam desses tecidos. Minas em folhas são freqüentemente visíveis na folha em forma de serpentina, manchas ou outras formas características de tecido descolorido. Modificações morfológicas e anatômicas causadas por minadores em folhas de Vismia guianensis (Aubl.) Choisy são apresentadas neste trabalho, com o objetivo de elucidar a sua estrutura e contribuir com os estudos sobre interação inseto-planta. Folhas sadias e minadas de trinta indivíduos foram coletadas e levadas ao laboratório. Para cada ramo coletado foram mensurados o número total de folhas jovens e maduras, o número de folhas minadas e o número de minas por folha. Secções transversais de folhas sadias e minadas foram obtidas para observar aspectos morfo-anatômicos. Das 1.438 folhas maduras e 379 folhas jovens analisadas, $214(14,9 \%)$ e $70(18,5 \%)$ estavam minadas e muitas dessas folhas $(67 \%)$ apresentavam uma única mina. Secções transversais das folhas minadas revelaram que a larva consome apenas tecido parenquimático do mesofilo e a epiderme permanece intacta. Não foi observado um padrão das minas 
foliares, mas a larva não consome as drusas observadas no mesofilo e os tecidos vasculares das nervuras central e laterais.

Palavras-chave: anatomia vegetal, hiponoma, mina foliar, interação planta-herbívoro, Clusiaceae.

\section{INTRODUCTION}

Mines or hyponomes are channels caused by larva miners consuming internal plant tissues. These miners live on the leaf and feed from these tissues. (Hering, 1951).

A leaf miner is a species, the larva of which lives and feeds for part of all of its time in the parenchyma. The duration of leaf mining can be as short as a single instar in some taxa or as long as the entire larval and pupal period. Mining insect habits range from gall making and deeper plant boring to external feeders and scavengers. Leaf mines are usually visible on the exterior of the leaf as serpentine paths, blotches, or other characteristic shapes of discolored tissues (Connor \& Taverner, 1997). The mine may be established in the parenchyma of various parts of the plant, such as the root, stem, flower, fruit leaf or petiole (Hering, 1951). Insects of four orders have evolved leafmining habits: Coleoptera (beetles), Lepidoptera (moths), Diptera (flies), and Hymenoptera (sawflies). These are orders with complete metamorphosis and considered to have the most extreme degrees of specialization among insects. Their adults are able to fly and to select the appropriate host plant for their larvae. Only the larvae are able to live in the interior of leaves.

The mining habit has evolved several times independently (Labandeira et al., 1994). The hypotheses commonly used to explain the adaptive value of leaf mining is to escape from natural enemies (predators, parasites, pathogens); protection from the physical environment (desiccation, UV radiation, dislodgment by weather), avoidance of plant defenses (selective feeding to maximize intake of most nutritious/least noxious tissues) (Connor \& Taverner, 1997).

In the Neotropical region there are few studies on leaf mines, although they are biologically as prevalent as in other regions (Connor \& Taverner, 1997). The first paper on the morphology and anatomy of leaf mine in Brazilian plants native to Serra do Cipó was Melo-de-Pinna et al. (2002) in Richterago riparia (Asteraceae). In this paper, the authors underscore the distinction of two different kinds of endophytophagy, those that form galls with induced formation of new tissue in the host plant, and those that form mines, where such processes do not take place. The aim of the present paper is to describe and discuss the morphological and anatomical modifications undergone by mined leaves of Vismia guianensis.

\section{MATERIALS AND METHODS}

Material from Vismia guianensis was collected at the Parque Estadual Dois Irmãos ( $7^{\circ} 55^{\prime} 43^{\prime \prime}$ $8^{\circ} 09^{\prime} 17^{\prime \prime} \mathrm{S} ; 34^{\circ} 52^{\prime} 05^{\prime \prime}-35^{\circ} 00^{\prime}$ 59” 'W), a 390 ha fragment of Atlantic forest near Recife, Pernambuco state, Northeast Brazil. The climate is tropical, with $2.460 \mathrm{~mm}$ yr-1 of rainfall, and vegetation can be classified as a tropical lowland rain forest (terra firme forest) (Veloso et al., 1991).

Vismiaguianensis(Aubl.)Choisy(Clusiaceae) is a pioneer woody species, native from Tropical America which can be found in Colombia, Venezuela, Guyana and Brazil (Ewan, 1962). This species is very important in the Atlantic secondary forest composition appearing at the edge of the forest (pers. comm.). It is known for supplying wood to civil construction, deluxe joinery and carpentry. A gomo-resinous, red-orange juice, resolutive and strongly purgative, also used in the treatment of skin diseases is obtained by incising the stem bark (Pio Corrêa, 1926).

Healthy and mined leaves were harvested at random from thirty plants and brought to the laboratory. The total number of young and mature leaves, the number of leaves with mines and the number of mines per leaf were counted.

We measured the total area of 70 leaves and the total area of leaf mining by placing a clear plastic grid $\left(1 \mathrm{~mm}^{2}\right)$ over the blade of the leaf and counting the squares over the relevant areas (Coley, 1996). For each leaf, we calculated the percentage of area occupied by mine: 0-25 (I); 26-50 (II); 51-75 (III); and 76-100\% (IV).

Healthy and mined leaves were fixed in FAA (formalin, acetic acid and 50\% ethanol, 1:1:18, 
$\mathrm{v} / \mathrm{v}$ ) (Johansen, 1940) for $48 \mathrm{~h}$. After fixation they were dehydrated in $50 \%$ and $70 \%$ ethanol. Leaves were cleared according to Foster (1950, in Kraus $\&$ Arduin, 1997). Transverse sections of the nonaffected leaf and leaf mine were obtained using razor blades and stained with astra blue and basic fuchsin (Kraus et al., 1998).

\section{RESULTS}

We harvested a total of 1,818 leaves, of which 1,438 were mature leaves $(79.1 \%)$ and 379 young leaves $(20.8 \%)$. Of these, 214 mature leaves $(14.9 \%)$ and 70 young leaves $(18.5 \%)$ were mined.

Fig. 1 shows the leaf area occupied by the mine. We observed fifty percent of the leaves bearing less than $25 \%$ of the total leaf area (Fig. 1a), 30\% in class II (Fig. 1b) and 17\% class III. Just $3 \%$ of the leaves were classified in class IV, indicating that more than $76 \%$ of the total leaf area was occupied by mines.

For the number of mines per leaf, we observed one to four mines per leaf. Sixty seven percent of the leaves presented just one mine per leaf, $22 \%$ two (Fig. 1a), 8\% three, and 3\% four mines per leaf. In most of the leaves showing more than one mine per leaf, we observed that at the beginning of the mine, they were individual however afterwards they were unified.

The leaves are opposite, simple, entire, with pinnate venation. The channel or mine occurred at the apical or base of the leaf. Fig. 1 shows the adaxial surface of two mined leaves with two (Fig. 1a) and three mines (Fig. 1b) with a percentage of area occupied by mine bear to the class I and II, respectively.

On the non-affected leaf, multicellular trichomes on the abaxial surface appeared. The mesophyll is bilateral, with palisade parenchyma on the adaxial surface. Idioblast containing druses were observed on mesophyll and secretory cells present only in the spongy parenchyma (Figs. 2a and $2 b$ ). The endodermis surrounds the pericycle (bundle sheath), showing parenchymatic cells (Fig. 2b).

Figs. $2 \mathrm{c}$ and $2 \mathrm{~d}$ shows leaf mines with the channel as a consequence of the consumption of the internal plant tissues. Transverse sections of the mine revealed that the larva consumed only mesophyll parenchyma tissue on the abaxial and adaxial surface, and left the epidermis and its stomata intact.

There is not a pattern of leaf mining, but the larvae did not consume the druses observed on the mesophyll nor the vascular tissues of the mid-vein and lateral vein. Therefore some aspects of the leaf could be pointed out as an obstacle to the larvae: 1) the vascular system is not consumed by the larvae, avoiding the vascular feixes eating only the parenchymatic cells; and 2) idioblastos with druses distributed at random in all mesophyll region.

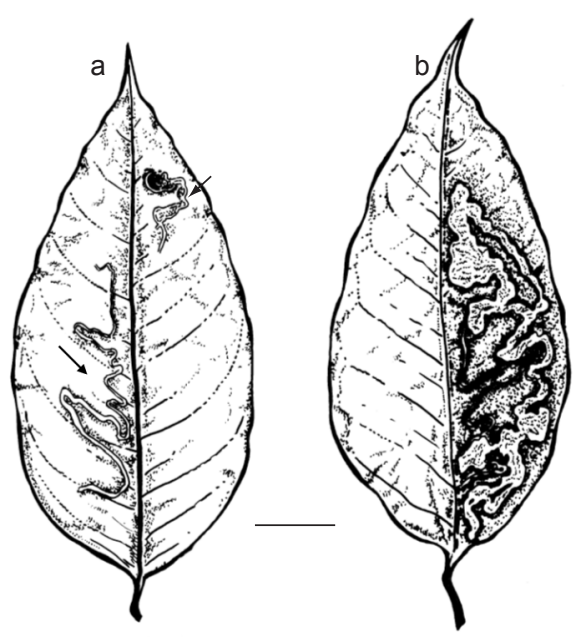

Fig. 1 - Mined leaves of Vismia guianensis. a) Leaf with two mines (arrows); and b) only one mine. Bars $=2 \mathrm{~cm}$. 


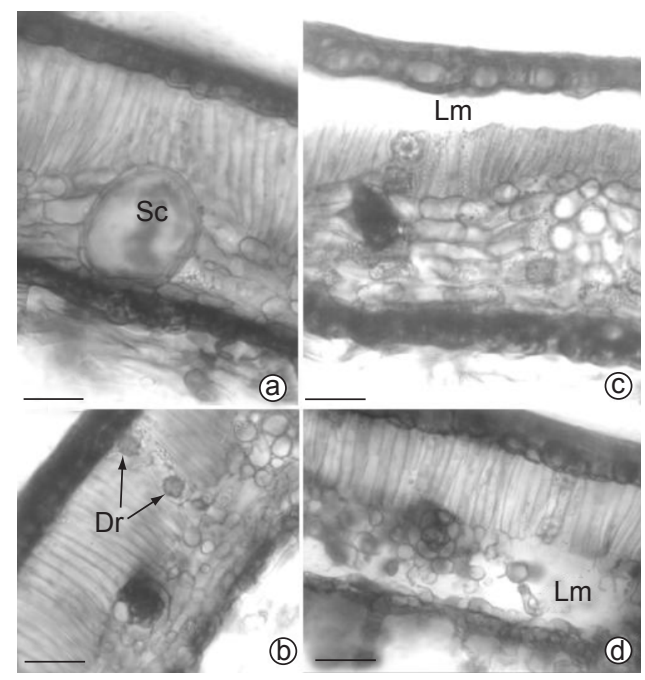

Fig. 2 - a,b) Transverse sections of leaves of Vismia guianensis a) Non-affected leaf showing bilateral mesophyll, with palisade parenchyma on adaxial surface and secretory cell present in the spongy parenchyma. b) Non-affected leaf with vascular bundle (arrow) and druses. c,d) Transverse section of the mine with mesophyll parenchyma tissue on the adaxial c) and abaxial surface d) consumed and the epidermis remains intact. The sections were stained with astra blue and basic fuchsin. $\mathrm{Sc}=$ secretory cell; $\mathrm{Dr}=$ druses $; \mathrm{Lm}=$ leaf mine; and Bars $=100 \mu \mathrm{m}$.

\section{DISCUSSION}

We observed a higher percentage of young leaves mined (20.8\%) than mature leaves $(14.9 \%)$ in Vismia guianensis corroborated with the data of Wilson and Faeth (2001), to Cameraria sp that showed a preference to young leaves of pioneer species.

Many folivorous insect species that feed on trees prefer and perform better on younger leaves than older ones (Feeny, 1970; Coley, 1980; Faeth \& Rooney, 1993). As leaves age, they change in surface area, water content, toughness, thickness, chemical composition and nutritional quality (Feeny, 1970; Coley, 1980). In contrast to external feeders, mining larvae only consume certain plant substances; the larvae become more selective than free-living forms and are specialized in certain substances, in which they rely on for their nourishment (Hering, 1951). Furthermore we registered a higher percent of leaves bearing just one mine per leaf. This reflected in the total leaf area occupied by mines, i.e. half of the leaves observed with mines present less than $25 \%$ of the total leaf area damaged by the mine. Coffea (Medina-Filho et al., 1977) is one example of plant-insect interaction being negative to the plant. The Coffea species are susceptible to the leafminer Leucoptera coffeella, which is responsible for production losses because the premature leaves fall and there is consequent reduction of the photossynthetic area (Magalhães, 1964). In Vismia guianensis, the damage caused by the miners could be considerably low due to the photosynthetic area being lost which is less than $25 \%$ of the total area, in general. We did not observe early leaf losses of leaves bearing mines.

Wound tissue is commonly formed in regions of wound (Lipetz, 1970) and, according to Cutter (1978), has a general protective role caused by an abiotic or biotic nature. The nature biotic is well illustrated by miners of Richterago riparia (Melo-de-Pinna et al., 2002) and of Vismia guianensis.

The leaf mine of $V$. guianensis occur in both surface epidermis, likely to have been observed by Melo-de-Pinna et al. (2002) in Richterago riparia (Asteracea). The authors observed that larvae consumed the parenchyma tissue and are characterized as a parenchymatic mine according to Hering (1951). In the present study, the mine observed can also be classified as parenchymal mining. Even if the internal structure of the mined leaf in both cases are very similar, it is important to note that in Richetago riparia the authors observed the larvae feeding the smallest veins, which was 
not observed in Vismia giuianensis. According to Hering (1951), in general the leaf miner food consists of palisade cells, the parenchyma, and the oozing sap. Veins sometimes impede the miners so that they must dwell in a confined area. Some larvae are adept to avoiding latex and resinous cells which can have toxic chemicals that not only deter non-host insects but have little effect on adapted leaf miners.

Melo-de-Pinna et al. (2002) discussed the absence of the new tissue formation in the mine of the Richterago riparia and they also pointed out that these facts corroborate with what was postulated by Hering (1951), that mines are galls at an incipient stage of differentiation. According to Mani (1964) the plant tissue may be passive or they react with some cell proliferation. The structural analysis of the mine of $V$. guianensis revealed that the plant tissues remain relatively passive. In other words, there is no cell proliferation characterizing the formation of the mine based upon the absence of neoformed tissues for feeding the larvae.

Acknowledgments - We thank Dr. Marccus Alves for thoughtful comments on the manuscript.

\section{REFERENCES}

COLEY, P. D., 1980, Effects of leaf age and plant life history on patterns of herbivory. Nature, 284: 545-546.

COLEY, P. D., 1996, Rates of herbivory on different tropical trees, pp. 123-132. In: E. G. Leigh, A. S. Rand \& D. M. Windsor (eds.), The ecology of a tropical forest: seasonal rhythms and long-term changes. Smithsonian Inst., Washington, D. C.

CONNOR, E. F. \& TAVERNER, M. P., 1997, The evolution and adaptative significance of leaf-mining habit. Oikos, 79: 6-25

CUTTER, E. G., 1978, Plant anatomy. Part I: cells and tissue. Edward Arnold, London, 315p.

EWAN, J., 1962, Synopsis of the south american species of Vismia (Guttiferae). Bull. of the Unit. States Nat. Mus., 35: 293-373.
FAETH, S. H. \& ROONEY, R. F., III. 1993. Variable budbreak and insect folivory of Gambel oak (Quercus gambelii: Fagaceae). The Southwestern Naturalist, 38: 1-8.

FEENY, P., 1970, Seasonal changes in oak leaf tannins and nutrients as a cause of spring feeding by winter moth caterpillars. Ecology, 51: 565-581.

HERING, E. M., 1951, Biology of the leaf miners. Dr. W. Junk Gravenhage, Berlin, 420p.

JOHANSEN, D., 1940, Plant microtechnique Mcgranw. Hill book co. Inc., New York, 523p.

KRAUS, J. E. \& ARDUIM, M., 1997, Manual básico de métodos em morfologia vegetal. Editora Universidade Rural, seropédica. 198p.

KRAUS, J. E., SOUSA, H. C., REZENDE, M. H., CASTRO, N. M., VECCHI, C. \& LUQUE R., 1998, Astra blue and basic fuchsin double stainig of plant materials. Biotech. \& Histoch, 73: 235-248.

LABANDEIRA, C. C., DILCHER, D. L., DAVIS, D. R. \& WAGNER, D. L., 1994, Ninety-seven million years of angiosperm-insect association: paleobiological insights into the meaning of coevolution. Proc Nat Acad. Sci. USA 91: 12278-12282.

LIPETZ, J., 1970, Wound healing in higher plants. Int. Rev. Cytol., 27: 1-28.

MAGALHÃES, A. C. N., 1964, Efeito da redução da superfície foliar sobre o desenvolvimento de cafeeiros. Bragantia, 23: 337-342.

MANI, M. S., 1964, Ecology of plant galls. Dr. W. Junk Publishers, The Hague, 434p.

MEDINA-FILHO, H. P., CARVALHO, A., MÔNACO, L.C., 1977, Melhoramento do cafeeiro. XXXVII, Observações sobre a resistência do cafeeiro ao bicho mineiro. Bragantia, 36: 131-137.

MELO-DE-PINNA, G. F. A., KRAUS, J. E. \& Menezes, N. L., 2002, Morphology and anatomy of leaf mine in Richterago riparia roque (Asteraceae) in the campos rupestres of Serra do Cipó. Braz. J. Biol., 62:179-185.

PIO CORRÊA, M., 1926, Dicionário das plantas úteis do Brasil e das exóticas cultivadas. Ministério da Agricultura, Rio de Janeiro, $1^{\circ}$ vol., 500. 24.

VELOSO, H. P., RANGEL-FILHO, A. L. \& LIMA, J. C. A., 1991, Classificação da vegetação brasileira adaptada a um sistema universal. IBGE, Rio de Janeiro.

WILSON, D. \& FAETH, H. S., 2001, Do fungal endophytes result in selection for leafminer ovipositional preference? Ecology, 82:1097-1111. 